\title{
Integrated Reading Strategy
}

\author{
Akhmad HB, Kuzairi \\ Indonesian Language and Literature Education Study Program \\ STKIP PGRI Banjarmasin \\ Banjarmasin, Indonesia \\ akhmadhb@stkipbjm.ac.id
}

\begin{abstract}
Based on preliminary reflection, it was found that integrated reading learning strategy which was implemented in school was not optimal especially in conference model development. Therefore, it requires a strategy that is able to optimize learning reading by using conference model to achieve learning objectives in the curriculum. This study employed qualitative method which used Classroom Action Research design. The sample consisted of the $7^{\text {th }}$ grade students of Junior High School. Data analysis was conducted by using flow data model analysis (reduction stage, data presentation, and conclusion drawing). Peer-discussion and triangulation method were also conducted to ensure the validity of the data. The result of this study showed that reading strategy at prereading stage was able to develop schema and students' reading interests. At whilst reading stage, the students' skill in comprehending the text can be developed. At post reading stage, the students' skill in responding the text through conference activities can also be developed. Integrated reading learning strategy covers three stages. Those are (a) Pre-reading stage: Introduction activity, (b) whilst reading stage: individual reading, and (c) post reading: having conference activity.
\end{abstract}

Keywords-Conference Model, Integrated Reading

\section{INTRODUCTION}

In the "whole language" oriented curriculum, reading is required to be integrated with listening, speaking and writing. One of the learning models that can integrate reading and those three other skills is conference model. Through conference model learning strategy, the students' ability is not only oriented in developing moral values and comprehension skill of the text content, but also in developing students' ability in responding the text. The opportunities in responding the text are provided during reading and conference activity between teacher and students so that students get opportunities to interact and transact towards texts as the main reading activities.

Based on this framework, it is necessary to have reading model that can provide reading activity in dynamic interaction. One of alternative learning models that can meet this expectation is conference reading learning model. In order to achieve this learning model, it is necessary to conduct a research on integrated learning strategy.

Based on the preliminary study, integrated reading learning is less optimal. Based on the result of observation on teaching and learning activities and interview with the teacher and students, some considerations were found as follows: (1) Reading sources in the school library are not utilized well yet; (2) Reading activity is only oriented on developing the ability to comprehend literal aspects; (3) Four language skills do not seem to be integrated optimally; (4) In reading instruction, students are not involved actively in choosing reading sources that can make the students happy to read so that they can be more active to interact with reading texts; (5) Intensive interaction between teacher and students less happened. In reading instruction, the students are only asked to (a) read by turns, (b) read and summarize the texts, or (c) read and answer questions by turns in front of their friends; (6) Some students' quite high reading motivations are less developed

Based on the preliminary reflection, it can be interpreted that integrated reading instruction is not yet implemented optimally. The learning target in the curriculum leads the students to be able to give impression on the story, tell the content of the story, or tell the interesting parts of the story. Therefore, it is necessary to use a strategy that can optimize integrated reading instruction through conference model to achieve learning objectives that is proposed in the curriculum. One of the alternative strategies is integrated reading learning strategy through conference model. Empirically, the problems that are necessary to answer in implementing this strategy are: (1) at pre-reading stage, how is the integrated reading strategy through conference model that can develop students' scheme and motivation towards fiction prose by conference model, (2) at whilst reading, how is the integrated reading strategy through conference model that can develop students' ability in comprehending and responding by conference model, (3) at post reading, how is the integrated reading strategy through conference model that can develop students' response and socialization by conference model, (4) which learning strategy is appropriate to be the integrated with reading strategy through conference model?

Regarding the research questions, this study aimed to create integrated learning strategy dealing with this following concerns: (1) integrated reading strategy through conference model that can develop schema and students' motivation through conference model at pre-reading stage; (2) integrated reading strategy through conference model that can develop students' comprehension on the text content through conference model at whilst reading stage; (3) integrated 
reading strategy through conference model that can develop students' ability in responding the text content and students' socialization through conference model at post reading stage; (4) appropriate learning strategy for integrated reading strategy through conference model.

Theoretically, the result of this study is expected to contribute a theory of integrated reading strategy that is achieved empirically based on observation and positive feedback towards learning activities. The findings of integrated reading strategy is expected to be able to be basic theory in developing students' moral values in the future.

\section{BASES OF INTEGRATED READING LEARNING}

The development of cultural and character education is strategic for the national sustainability and merits in the future [1]. This development should be carried through good planning, appropriate approach, and effective learning method. In accordance with the character values, cultural and character educations are conducted together by all of the teachers and the school stakeholders, through all of the subjects, and being integrated part with the school culture.

The bases on integrated reading learning consist of (1) operational base, namely curriculum, (2) theoretical base that covers approach base, student development theory, and reading strategy. Integrated reading is oriented on integrated approach and communicative approach.

Integrated approach orientation is found in these criteria: (1) In learning implementation, language components, comprehension and usage are delivered integrally but in learning activity, teacher can focus on one of the components; (2) Language learning covers listening, speaking, reading and writing aspects. These four aspects should have equal portion. It should be done integrally in the implementation, for example: Listening---Writing--Discussing; Listening---Speaking---Writing; Speaking--Writing --- Reading; Reading---Discussing ---Role Playing; Writing---Reporting --- Discussing; (3) Integration of language learning and literature should be balanced and able to be delivered integrally. For example, discourse literature can be used as language learning sources all at once; (4) Vocabulary learning is delivered in discourse context and it is integrated with learning activities such as conversation, reading, writing and literature learning; (5) Language and literature learning can be integrated with other subjects to develop moral values.

Reading objectives that are integrated with literacy critical imaginative mode in reading instruction can be oriented on reading story. The taken story should be based on students' thinking level, fictional imagination of the story, interesting aspect of the story that students can respond critically and imaginatively. This selection is in line with the result of study by Van Klinken [2] which shows that reading source that students are interested in is story.

Discourse literacy in this context is in line with the concept of discourse literacy [3]. It is critical and imaginative mode Discourse literacy. This discourse literacy can also be oriented on expert or advanced literacy level after beginning, basic and intermediate level. Expert literacy level is indicated by ability in comprehending, summarizing, and explaining information in the text, while advanced literacy is indicated by ability in synthesizing and taking lesson from the content of the text [4].

\section{METHOD}

The method of this study was qualitative research design through classroom action research. The procedures of this study covered preliminary study, planning, action, observation, and reflection. Preliminary study was conducted at observed integrated reading learning strategy through conference model to get preliminary reflection. Planning stage was conducted by designing action procedures, searching for source of data, determining the action sources, and determining observation form of the action. Action was done by observation and followed by reflection on action implementation [5].

This study was conducted in the $7^{\text {th }}$ grade of Junior High School by using three action cycles. It was selected 32 students as the sample of the study. The data of this study were process and result of activity data from the results of observation, interviews, and notes collection on each revised action of integrated reading strategy through conference model. Observation in general was conducted for all of students that represented high group, average group, and low group. The main instrument of this study was the researchers themselves who played as data collector through observation, interviews, and documentation. Data analysis was conducted by using flow data model analysis starting from data reduction stage, data presentation, and conclusion drawing. Peer-discussion and triangulation method were also conducted to ensure the validity of the data.

\section{FINDINGS AND DISCUSSION}

Most of the activities in integrated reading strategy through conference model were conducted well in general. The absent activities were group conference and sharing the result of reading by the students in front of the teacher and their friends. Those two activities were not conducted because both were group activities that needed habitual process through special research.

The results of this study showed that learning strategy that can develop schemata and students' motivation at prereading stage was indicated by the role of teacher as facilitator and motivator in students' learning activities. In implementing the activities, teacher (1) prepares several books, (2) shows the books, (3) gives guided question to raise knowledge and experience about the books and content prediction, (4) gives question models to comprehend and respond, (5) explains the purpose of reading, (6) explains how to fill in the reading journal, and (7) gives the students opportunity to choose books. The learning outcome at pre- 
reading stage is the development of students' scheme towards the book and motivation to read. Students' scheme towards the book was indicated by making prediction of the beginning and the ending of the book, describing pictures, telling the title and author. The development of students' motivation to read was indicated by students' activity in searching, choosing, borrowing, and reading books which were very high for observed students whereas other several students were quite high.

Integrated reading strategy through conference model at whilst reading that can develop students' ability is comprehending the book contents indicated by the role of teacher as facilitator, monitor, and participant in learning activities. Teacher's activities are (1) giving opportunity for students to have silent reading, (2) participating in reading, (3) monitoring students' reading activity, and (4) telling the students to prepare and fill in the reading journal. The learning outcome at whilst reading is the development of students' ability in comprehending the book content that is indicated by describing the content, identifying the main character, describing the character, explaining important events, and telling the plot. The level of ability qualification in comprehending the book content of the three observed groups was quite high.

Integrated reading strategy through conference model at post reading stage that can develop students' ability in responding the book and socialization of the students was indicated by the role of teacher as motivator, facilitator, and counselor by conducting activities such as (1) preparing conference schedule and notes, (2) calling the students to have conference by discussing and questioning \& answering on students response toward the content of the story, pictures and characters in the book, (4) giving opportunity for students to read aloud the book that students like and planning the following reading activity, (5) giving attention on student who is having conference by observing, showing positive reaction, motivating students, and (6) taking notes conference results, students' strength and shortcoming, and general evaluation. The learning outcome at post reading stage was the development of students' ability in responding the book indicated by stating impression and empathy towards the main character, correlating content of the book to their own experiences, and stating impression on the story illustration. Besides, it also developed socialization ability which was indicated by bringing the reading journal in the conference, speaking actively at the conference, actively listening to the speaker, and being able to answer questions during the conference. The qualification of comprehension and socialization ability of the observed students was in high average. The results are consistent with the concept of discourse literacy [3].

\section{CONCLUSION}

From the findings, it can be concluded that (1) Reading strategy that can be used as integrated reading learning model covers three stages, namely (a) pre-reading (introduction activity), (b) whilst reading (individual reading activity), and (c) post reading (conference activity). (2) Integrated reading strategy can develop schemata and students' motivation at pre-reading stage. (3) Integrated reading strategy through conference model can develop students' ability to comprehend the book contents at whilst reading, (3) Integrated reading strategy through conference model can develop students' ability in responding the book and socialization of the students at post reading stage.

Based on the findings and conclusion, it is suggested for experts to utilize the result of this study as theoretical reference in developing integrated reading strategy that concerns on integrated reading strategy through conference model. It is also recommended for other researchers to transfer this study into other schools by conducting similar research issues.

It is suggested for teachers to optimize the process and results of integrated reading through conference model by utilizing integrated reading strategy through conference model in the classroom. Teacher is expected to develop his or her roles as facilitator, motivator, participant, monitor, and counselor in integrated reading learning through conference model in the classroom. Besides, teacher is also expected to improve students' activity by stimulating involvement in students' emotion, cares, motivation and perseverance in integrated reading through conference model. It is suggested for parents to give scaffolding reading activities for their children at home by providing reading sources and getting involved in reading activities to create and develop students' motivation and interest well.

\section{REFERENCES}

[1] Hasan, "Pengembangan Pendidikan Budaya dan Karakter Bangsa (Bahan Pelatihan Penguatan Metodologi Pembelajaran Berdasarkan Nilai-Nilai Budaya untuk Membentuk Daya Saing Bangsa dan Karakter Bangsa)," BPPPK Kemendiknas, Jakarta, 2010.

[2] B. K. Purwo, "Pengajaran Bahasa Indonesia di Sekolah Dasar," in Konferensi Nasional Ke Enam Masyarakat Linguistik Indonesia, Semarang, 1991.

[3] J. T. Raka, "Pembentukan Nilai-Nilai Moral. Tantangan Bagi Pendidikan dasar Menyongsong Abad Informasi," in Seminar Nasional Pengajaran Bahasa dan Sastra Indonesia IKIP Malang, Malang, 1990.

[4] Hasanah, "Strategi Pembelajaran Membaca Prosa Fiksi Siswa Sekolah Dasar," Jurnal Pengajaran Bahasa dan Seni PBSI IKIP Malang, 1998.

[5] A. A. Chaedar, Pokok Action Research: Dasar-Dasar Merancang dan Melakukan Penelitian Kualitatif, Bandung: Kiblat, 2010. 